TTR

Traduction, terminologie, rédaction

\title{
The Multiple Lives of Translators
}

\section{Reine Meylaerts}

Volume 26, numéro 2, 2e semestre 2013

Traduction et conscience sociale. Autour de la pensée de Daniel Simeoni

Translation as Social Conscience. Around the Work of Daniel Simeoni

URI : https://id.erudit.org/iderudit/1037134ar

DOI : https://doi.org/10.7202/1037134ar

Aller au sommaire du numéro

\section{Éditeur(s)}

Association canadienne de traductologie

ISSN

0835-8443 (imprimé)

1708-2188 (numérique)

Découvrir la revue

Citer cet article

Meylaerts, R. (2013). The Multiple Lives of Translators. TTR, 26(2), 103-128.

https://doi.org/10.7202/1037134ar

\section{Résumé de l'article}

L'appel de Daniel Simeoni à compléter le concept traductologique de 'normes' par un complément d'acteur et son introduction subséquente de la notion d’habitus s'est révélé pionnier. La Traductologie a notamment bénéficié du concept d'habitus pour comprendre le traducteur/interprète comme un professionnel. Toutefois, comme cela avait déjà été signalé par Simeoni (1998), l'habitus du traducteur ne peut être réduit à son expertise professionnelle en tant que traducteur. Le présent article développe cette observation en soutenant que l'habitus pluriel et dynamique du traducteur (Lahire, 2004) réfère également à un individu socialisé avec diverses positions et perceptions dans d'autres champs (p. ex., le champ littéraire pour un traducteur littéraire, surtout lorsqu'il est romancier ou critique lui-même) dont il serait artificiel d'isoler l'habitus traductionnel. Une compréhension nuancée des auto-perceptions et rôles des traducteurs littéraires dans l'histoire culturelle demande des analyses détaillées de leur habitus interculturel dynamique et pluriel dans toutes ses complexités. Celles-ci révéleront la multi-positionalité des traducteurs à travers les frontières nationales et linguistiques, et à travers les divers champs artistiques ainsi que les objectifs, les formes et les fonctions de leurs multiples activités de transfert, par exemple, pour construire une culture nationale ou internationale. Ces analyses peuvent aussi contribuer à un modèle renouvelé pour des historiographies culturelles interdisciplinaires et interculturelles, incorporant la traduction au sein d'une multitude d'activités de transfert (traduction, auto-traduction, etc.). À titre d'exemple, cet article analyse l'habitus d'un traducteur littéraire du début du $\mathrm{XX}^{\mathrm{e}}$ siècle en Belgique.
Ce document est protégé par la loi sur le droit d'auteur. L'utilisation des services d'Érudit (y compris la reproduction) est assujettie à sa politique d'utilisation que vous pouvez consulter en ligne.

https://apropos.erudit.org/fr/usagers/politique-dutilisation/ 


\title{
The Multiple Lives of Translators ${ }^{1}$
}

\author{
Reine Meylaerts \\ Centre for Translation Studies at KU Leuven
}

\begin{abstract}
Daniel Simeoni's call for an actor-based complement to the concept of norms in Translation Studies and its subsequent introduction of the habitus concept has revealed groundbreaking. Among other things, Translation Studies has benefited from using habitus as a conceptual tool to comprehend the translator/interpreter as a professional. However, as already pointed out by Simeoni 1998, a translator's habitus cannot be reduced to his/her professional expertise as a translator. The present essay takes this observation a step further and argues that a translator's plural and dynamic habitus (Lahire, 2004) also stands for a socialized individual with various positions and perceptions in other fields (e.g. the literary field for a literary translator especially when he/she is a novelist or critic him/ herself) of which it would be artificial to isolate the translatorial habitus. A nuanced understanding of literary translators' self-images and roles in cultural history asks for fine-grained analyses of their dynamic and plural intercultural habitus in all its complexities. It will lay bare translators' multipositionality across linguistic, national and field-specific boundaries and the perceived aims, forms and functions of their multiple transfer activities, e.g. for the establishing of a national or international culture. Such an analysis may also contribute to a renewed model for interdisciplinary and intercultural historiographies of culture embedding translation within a multitude of transfer activities (translation, self-translation, etc.). As an illustration hereof, this essay analyzes a literary translator's habitus in early 20th century Belgium.
\end{abstract}

Keywords: habitus, transfer, selftranslation, multilingual writing, interculturality

Résumé

L'appel de Daniel Simeoni à compléter le concept traductologique de 'normes' par un complément d'acteur et son introduction subséquente de

1. This article came into being in the context of the Research Project "Customs officers or smugglers? The mediating role of intercultural actors within Belgium and between Belgium and France (1850-1920)", funded by the KU Leuven Special Research Fund (BOF). 
la notion d'habitus s'est révélé pionnier. La Traductologie a notamment bénéficié du concept d'habitus pour comprendre le traducteur/interprète comme un professionnel. Toutefois, comme cela avait déjà été signalé par Simeoni (1998), l'habitus du traducteur ne peut être réduit à son expertise professionnelle en tant que traducteur. Le présent article développe cette observation en soutenant que l'habitus pluriel et dynamique du traducteur (Lahire, 2004) réfère également à un individu socialisé avec diverses positions et perceptions dans d'autres champs (p. ex., le champ littéraire pour un traducteur littéraire, surtout lorsqu'il est romancier ou critique lui-même) dont il serait artificiel d'isoler l'habitus traductionnel. Une compréhension nuancée des auto-perceptions et rôles des traducteurs littéraires dans l'histoire culturelle demande des analyses détaillées de leur habitus interculturel dynamique et pluriel dans toutes ses complexités. Celles-ci révéleront la multi-positionalité des traducteurs à travers les frontières nationales et linguistiques, et à travers les divers champs artistiques ainsi que les objectifs, les formes et les fonctions de leurs multiples activités de transfert, par exemple, pour construire une culture nationale ou internationale. Ces analyses peuvent aussi contribuer à un modèle renouvelé pour des historiographies culturelles interdisciplinaires et interculturelles, incorporant la traduction au sein d'une multitude d'activités de transfert (traduction, auto-traduction, etc.). À titre d'exemple, cet article analyse l'habitus d'un traducteur littéraire du début du XX $\mathrm{XX}^{\mathrm{e}}$ siècle en Belgique.

Mots-clés: habitus, transfert, auto-traduction, écriture multilingue, interculturalité

\section{Introduction}

Since the 1990s, increased focus on the actors involved in the translation process has led to a better understanding of translating as a sociocultural practice that results from a variety of causes. Whereas Descriptive Translation Studies (DTS) and systems theory have paid particular attention to the translated text as a depersonalized construct of structural relationships since 1970, sociological models have emphasized the dialectical relationship between objective social structures and subjective social actors (Hanna, 2005). Jean-Marc Gouanvic (1997, 1999) was one of the pioneers of this approach who proposed using Bourdieu's sociology, with its concepts of field, habitus, capital and illusio, as a way to study the dialectic between structures and actors. Levelling the same legitimate criticism on the depersonalized character of DTS but without abandoning its basic concepts such as translation norms, Daniel Simeoni's (1998) call for an actor-based complement to the concept of norms in DTS 
and his subsequent introduction of the concept of habitus was groundbreaking. Since then the importance of habitus for translation research has been illustrated in different ways by various scholars: Sela-Sheffy (2005), Inghilleri (2003, 2005), Shlesinger and Sela-Sheffy (2011), Wolf and Fukari (2007), Meylaerts (2008), to name a few.

Although habitus is a category that originates from Aristotle (see Simeoni, 1998), Pierre Bourdieu's (1972) concept of habitus as the motor of a dialectic between a theory of effects (structure) and a theory of strategies (agency) is broadly accepted by translation scholars. Bourdieu wanted to escape from a philosophy of the subject without sacrificing the actors and to avoid a philosophy of structure without losing sight of the effects structure exerts on the actor. Bourdieu provided numerous definitions, including this early version from Esquisse d'une théorie de la pratique (1972):

des habitus, systèmes de dispositions durables, structures structurées prédisposées à fonctionner comme structures structurantes, c'est-à-dire en tant que principe de génération et de structuration de pratiques et de représentations qui peuvent être objectivement «réglées» et «régulières", objectivement adaptées à leur but sans supposer la visée consciente des fins et la maîtrise expresse des opérations nécessaires pour les atteindre et étant tout cela, collectivement orchestrées sans être le produit de l'action organisatrice d'un chef d'orchestre. (Bourdieu, 2000 [1972], p. 256)

This definition is resumed several pages later:

un système de dispositions durables et transposables qui, intégrant toutes les expériences passées, fonctionne à chaque moment comme une matrice de perceptions, d'appréciations et d'actions, et rend possible l'accomplissement de tâches infiniment différenciées, grâce aux transferts analogiques de schèmes permettant de résoudre les problèmes de même forme et grâce aux corrections incessantes des résultats obtenus, dialectiquement produites par ces résultats. (Bourdieu, 2000 [1972], pp. 261-262)

Habitus thus refers to the subject's internalized system of social structures in the form of dispositions. These dispositions 
are the result of an unconscious internalization of objective field structures. They are principles, attitudes, opinions, ways of thinking and acting that are the product of certain life conditions. The internalization of social structures is a life-long process of interactions between structure and agency through various and variable individual and collective experiences. Dispositions engender practices, perceptions and attitudes that are regular but not necessarily fixed or invariant. Under the influence of social position and individual and collective past, every cultural actor thus develops (and continues to develop) a social identity: a certain representation of the world and of his/her position therein.

Although in Esquisse d'une théorie de la pratique Bourdieu emphasizes the collective and permanent character of habitus, he also leaves space for restructuring and variation (Bourdieu, 2000 [1972], p. 284) as well as for a certain individualization:

L'histoire de l'individu n'étant jamais qu'une certaine spécification de l'histoire collective de son groupe ou de sa classe, on peut voir dans les systèmes de dispositions individuels des variantes structurales de l'habitus de groupe ou de classe. (ibid., p. 285)

He further posits elsewhere that:

Le principe des différences entre les habitus individuels réside dans la singularité des trajectoires sociales, auxquelles correspondent des séries de déterminations chronologiquement ordonnées et irréductibles les unes aux autres: l'habitus [...] réalise une intégration unique. (Bourdieu, 1980, p. 101-102)

Toward the end of the 1990s, when sociology became increasingly interested in an individual's diversity (rather than in his/her unity), the tension between the individual and collective and the permanent and variable elements of habitus received special attention. Bourdieu then referred to "des habitus déchirés, livrés à la contradiction et à la division contre soi-même, génératrice de souffrances" (Bourdieu, 1997, p. 190) as a way to

2. Bourdieu comes back to this idea elsewhere: "il est exclu que tous les membres de la même classe (ou même deux d'entre eux) aient fait les mêmes expériences et dans le même ordre" (Bourdieu, 1980, p. 100). 
better take into account the subject's plurality. As one of the most fervent advocates of the discontinuity of individual trajectories and of the plurality in every person's life, Bernard Lahire is one of the most severe critics of a unified and static habitus (Lahire, $1998,2001,2003,2004)$. Lahire breaks a lance for a dynamic and plural habitus: an individual's habitus is the result of multiple social experiences and confrontations with various field logics. The individual is thus a complex product of multiple processes of socialization in a variety of situations (family, school, friends, work, neighborhood, etc.). His/her dispositions to act and to think are the result of an unstable interplay of a fragmented, plural and sometimes even contradictory habitus.

In La condition littéraire: la double vie des écrivains (2006), Lahire devotes special attention to the "plus ou moins grandes variations intra-individuelles des comportements culturels" in synchrony as well as in diachrony. Moreover, he criticizes field theory because it "réduit la vie sociale et pratique des individus qui écrivent des textes littéraires à leur appartenance au champ littéraire (à leur être-comme-membre-du-champ).” (Lahire, 2006, p. 27) For him writers "ne se réduisent [...] pas à leur activité dans le champ [littéraire]" (ibid., p. 65) but practice their authorship often as a secondary activity, in addition to their "real" professional activity that enables them to support themselves. For Lahire, these writers' "double lives" are not an insignificant factor, on the contrary, they are a fundamental element of their literary life with important implications for their dispositions, i.e. for their self-perception, perception and writing practices. Indeed, for Lahire it is difficult to speak of a literary habitus sensu stricto in the case of a writer-teacher, writer-journalist, writer-doctor or writer-official because this would mean that these actors combine theoretically non-combinable habituses (ibid., p.67). As he remarks, "il est possible en revanche de décrire [...] les propriétés générales du travail des écrivains [...] en analysant les dispositions et compétences requises pour exercer un tel travail" (ibid., p. 495). Lahire is referring here not only to the pleasure or the internal need to read and write as they are formed by the writer's family background and schooling but also to more general and more specific dispositions and competences such as certain writing techniques or themes. 
These insights are also useful for the study of translators. So far, the focus of research on translators- their perception and action schemes concerning translating, their socialization process and their social trajectory-has been on the translator (as a translator) within the field of translation. In other words, the focus has been on the social actor in his/her (more or less) exclusive role as a professional translator (Simeoni, 1998; Sela-Sheffy, 2005; Inghilleri, 2003, 2005; Gambier, 2006). This view is based on two interrelated assumptions: 1 ) the existence of a more or less autonomous field of translation and 2) the vision of translation as an exclusive professional activity and the translator as a skilled professional. However, both assumptions are problematic in the case of literary translation. More than in the case of literature (Lahire, 2006; Sela-Sheffy, 2005), literary translation cannot be seen as a field in the narrow sense of the word. ${ }^{3}$ In many historical contexts, it is often a secondary activity that is executed at times sporadically, at times continuously, but frequently in addition to other literary and/or professional activities. The implication is that literary translators are often more than simply translators. Until a few decades ago, they rarely if ever enjoyed professional training as translators, and there were no special conditions for admission to the exercise of their translation activity. Salaries for literary translators are still very low. Literary translators therefore often combine their translation practice with a (literary) profession and/ or with a multitude of literary activities and transfer roles (writing, translating, adapting, self-translating, publishing, etc.) in varying combinations. Their individual habitus is the unique integration of their cultural socialization in terms of gender, family and social environment, academic career, professional career, partner, contacts with different social, political, religious and cultural institutions, friends, and so on. In other words, their translation practice, their perception and self-perception as a translator is inextricably linked to their socialization in other fields and can only be understood in relation to this socialization and in relation to the multitude of

3. Lahire speaks of the "jeu littéraire comme 'champ secondaire' d'activité, faiblement rémunérateur et, du même coup, très peu professionnalisé" (Lahire, 2006, p. 529). "La notion de 'jeu' me semble particulièrement adaptée pour désigner des activités qui, comme la littérature, se pratiquent à des degrés divers d'investissement très différents, mais qui, globalement, concernent des individus ne pouvant se permettre de passer tout leur temps à jouer ce jeu." (ibid., p. 73) 
(transfer) roles they take on. ${ }^{4}$ Following Lahire (see above), it is thus hard to speak of a translatorial habitus sensu stricto in the case of a literary translator-writer, literary translator-teacher, literary translator-journalist, literary translator-civil servant or some other combination because this would mean that these actors combine theoretically non-combinable habituses (Lahire, 2006, p. 67).

A nuanced understanding of literary translators' self-image, perceptions and transfer activities ${ }^{5}$ in cultural history therefore requires detailed analyses of their multipositionality as it relates to their multiple lives (as a professional teacher, journalist, civil servant, etc. and as a writer, critic, translator, self-translator, editor, etc.) and to their plural and variable socialisation in a variety of social and cultural contexts. As an illustration hereof, this essay will focus on Roger Avermaete, an intercultural mediator ${ }^{6}$ in early 20th century Belgium.

The following aspects are pertinent for this case:

1) Literary translation in early 20th century Belgium was not normally an exclusive professional activity but rather a secondary activity in addition to the actual professional life of the intercultural mediator. Moreover, it was usually part of an aggregate of partly overlapping literary (transfer) roles such as writing, translating, multilingual writing, self-translating and publishing.

2) These literary transfer roles, and especially those between Dutch and French-Belgian literature, took place against the background of an ongoing linguistic conflict, known as the language question, between French and Dutch-speaking groups. ${ }^{7}$

4. According to this line of reasoning, other professionals' habitus, shaped within a more autonomized field, are likely to be less characterized by multipositionality.

5. For reasons of time and space, I will not deal with translation practices here.

6. Because of the multiple roles and positions of the literary translator under study, we prefer to use the term intercultural mediator instead of the more narrow translator.

7. The language question has profoundly marked Belgium's sociocultural, sociopolitical, and institutional evolutions and even its existential crises. In 2011, Belgium broke the sad record of taking the longest time to form a Government precisely because of this language issue. In this context, it was repeatedly referred to as the "end of Belgium." For a more elaborate view, see Meylaerts $(2007,2009)$. 
The origin of this conflict was the institutionalization of French as the main language of the administration, the legal and political systems, education and the army while Dutch ${ }^{8}$, although spoken by a majority of the people, remained a less institutionalized minoritized language during the 19 th and early 20th centuries. In the North of the country, i.e. Flanders, linguistic oppositions went hand in hand with social stratification. The lower classes spoke Dutch (or rather, one of several Flemish dialects) while the upper classes spoke French; a large group of Flemings, mostly from the middle classes, were bilingual. As a consequence, people's socialization process was marked by their interiorizing the superiority of the dominant language and literature and the inferiority of the minority language and literature. However, the individual habitus realizes a unique integration of these hierarchies: some cultural actors will fully interiorize them, while others will oppose them in a more or less radical way. So, for example, while some Dutch speakers opted for a linguistic transfer, abandoning Dutch in favor of French, other Dutchspeaking groups opposed French dominance and claimed for Dutch an institutional and symbolic status equal to that of French. The first legal successes, giving more rights to the Dutchspeaking population, were obtained during the second half of the 19 th century and they continued into the first decades of the 20th century. Several laws in the areas of education, administration, justice and politics strengthened the position of Dutch in Flanders without fundamentally questioning, however, the dominance of French. These laws changed the structures of the respective fields, in particular regarding linguistic relationships and positions, and therefore also potentially affected the perceptions, self-perceptions and practices of intercultural mediators whose transfer roles were inextricably linked with linguistic, sociocultural and sociopolitical (op)positions. Socialization in late 19th and early 20th century Belgium was inevitably linguistic socialization via the domestic environment, the education, the professional career, the circle of

8. Dutch is the official term to refer to the language spoken in Flanders. Flemish refers to culture, ethnicity and identity, e.g. in the designation of the actual federalised institutions like the Flemish Community and the Flemish Region. Historically, as illustrated by various quotations in this article, the term Flemish also referred to the language, sometimes with a condescending flavour of "amalgam of dialects." 
friends, the (inter)cultural activities of cultural actors. ${ }^{9}$ Writing, translating, self-translating and multilingual writing were literary practices which, by definition, involved the risk of habitus-field clashes. $^{10}$

The following analysis will focus on those aspects that were particularly important for the transfer roles and the (self-) perception of a bilingual Fleming like Roger Avermaete.

\section{Multiple Lives}

Roger Avermaete was born on October 27, 1893, in Antwerp (Flanders), son of the merchant Oscar Avermaete and Barbara De Lattin. His mother was a native Antwerpian and his father was from Bruges. The parents were bilingual, middle-class Flemings: at home they usually spoke their mother tongue, the Antwerp dialect, but they were also fluent in French. As Avermaete himself stated years later in a television interview, they "liked to show off with their French." ${ }^{11}$ From his youth, Avermaete's socialization process was thus bilingual. He perceived French as the dominant language, the language of social prestige. Although school attendance until the age of 12 was not compulsory until 1914, Roger obtained a primary education. From 1900 to 1903 he attended the urban school "Van Maerlandtstraat" in Antwerp. This illustrates the parents' concern for the social promotion of their child. The choice of a non-Catholic school was nonconformist in predominantly Catholic Flanders at the turn of the 20th century. In other words, the young Avermaete and his entourage belonged to the non-confessional, liberal minority. "Van Maerlandtstraat" was one of several private primary schools in Antwerp attended by children of the bourgeoisie. They were considered hotbeds of Francization because all subjects in Dutch were also translated into French (Beckers, 1976,

9. In addition to linguistic oppositions, denominational oppositions between Catholics and free thinkers also played a (more limited) role. I will only indirectly examine these.

10. A habitus-field clash may occur through movement across or within fields (e.g. francophone vs. Dutch-language literature) when a subject's dispositions clash with a field's positions. It leads to the emergence of reflexivity and is more likely to occur in situations with multipositional actors. 11. "pakten [ze] gemakkelijk met hun Frans uit" (Florquin, 1962, p. 6). All English translations of primary Dutch sources are mine. 
p. 175). ${ }^{12}$ In line with his interiorization of French dominance, Avermaete considered this bilingual school socialization to be very positive: "If I think back to this time I'm still full of admiration for the former teaching staff. When I entered the state secondary school-directly into the second year-I knew, as a young Fleming, sufficient French to express myself rather well" (Letter to J. De Meyer, 28/11/1987). ${ }^{13}$ Between 1903 and 1909 Avermaete was a student at the Royal Athenaeum of Antwerp, again a non-denominational state school. He studied the modern humanities, given that the classical languages were "reserved for a very limited select audience." 14 The language of instruction was divided equally between French and Dutch, in accordance with the language law on secondary education at the time: his bilingual linguistic socialization was thus continued. In the overall context of schooling opportunities for a Flemish youngster at the end of the 19th century, Avermaete held an intermediate position. For his peers at Catholic (secondary) schools, French usually held a more important place. ${ }^{15}$ For students from the lower social classes enrolled in the free municipal schools, Dutch was instead the most important language.

Without having finished his secondary education, in 1910 Avermaete was hired as a clerk for the collector of the Charitable Office, later Commission of Social Security. He was successively

12. A law passed in 1876 by the Antwerp Municipal Council guaranteed that private primary schools would use Dutch as the language of instruction. In the second grade, 3 of the 22 hours would be given in French, and up to 7 out of 34 in the fifth grade. This directive was not followed; French had a much more important place. "Van Maerlandtstraat" had Dutch and French sections for the first three years; in the following years of study, all subjects were taught in Dutch and translated into French (Beckers, 1976, p. 175).

13. "Als ik an deze tijd terugdenk ben ik nog steeds vol bewondering voor het toenmalig leeraarkorps. Toen ik overging naar het Atheneum ineens naar de $5 \mathrm{e}$ - kende ik als jonge Vlaming voldoende frans (sic) om mij behoorlijk uit te drukken."

14. "toen gereserveerd aan een heel beperkt select publiek" (Florquin, 1962, p. 6).

15. The Church has always played an important role in education in Belgium, especially in catholic Flanders. Catholic schools had to form a barrier against the godless public schools. Since most prestigious (secondary) Catholic schools were Francophone in Flanders up until the 1930s, they were an important factor in the continuation of the existing language hierarchies. See also Wils (2008). 
promoted to assistant to the head of office (1919), head of office (1920), Auditor-General (1937) and Secretary-General (19451963). Because Antwerp, unlike other major Flemish cities, had declared Dutch to be the official language of the city in 1866, we can assume that Roger Avermaete mainly used Dutch in his professional life. However, his bilingualism was certainly useful for contacts with central services ${ }^{16}$ and for internal promotion exams where bilingualism was required. He owed, among other things, his promotion to assistant to the head of office just after World War I to his bilingualism (Denuit, 1978, p. 24). As Deputy Secretary of the National Congress for Charity, Health and Social Care in 1930, he was also a translator in both national languages. Throughout his life, Roger Avermaete was thus a bilingual officer whose administrative career took place largely in the minority language but whose bilingualism permitted upward social mobility.

In addition to his position as an official, Avermaete was also a teacher. From 1924 to 1930 he taught legislation and history of the charity at the School of Civil Service. In 1926 he founded and directed the vocational school of Art Crafts. From 1930 to 1940 he taught French literature at the Adult Education College for workers. From 1933 to 1958 he taught art history at the National Higher Institute for Fine Arts. These teaching activities were mainly conducted in Dutch. In 1919 he married Lucienne De Kinder, daughter of Flemish playwright and children's literature writer Constant De Kinder, hereby creating a bond with the (Flemish) literary scene. In 1920 his son Alain was born, with whom Roger Avermaete always spoke in French (Avermaete, 2011, n. p.). His private life, unlike his professional life, is therefore an example of linguistic transfer.

\section{Multiple Transfer Roles}

Avermaete's literary activities took place during his spare time. One of the most fundamental-often unconscious-choices that multilinguals face in a multilingual culture is the language of their literary activities. This choice is connected to their linguistic socialization during childhood, to their schooling and professional activities and to the way in which the individual habitus realizes a

16. Internal documents of the Office were in Dutch (see Van der Ven, 1909). 
unique integration of sociolinguistic and sociocultural hierarchies. Avermaete's entry into literature, right after World War I, occurred exclusively in French, and French always remained his main literary language. Despite the importance of education for one's linguistic and literary socialization (Lahire, 2006, p. 238), Avermaete described his initial choice of the dominant language not as the result of his bilingual socialization in school but as the "natural" consequence of a "natural" disposition to reading and self-teaching in the dominant language. ${ }^{17}$ Language choice thus became an individual, private matter rather than the structural result of linguistic institutionalization and hierarchies.

Mes débuts. Je n’en sais pas trop. [...] Je n'ai jamais été encouragé. Plutôt le contraire. Enfant unique, j'ai eu une enfance solitaire. Mes parents ne se sont jamais mêlés de me comprendre. J'ai été élevé en flamand. J'ai dévoré pendant des années tous les bouquins qui me tombaient sous la main, tous français. C'est l'unique raison, je crois, qui m'a fait écrire en cette langue. Je me souviens que j'ai pensé très tôt en français. Je jouais en français [monologue intérieur]. Je n'ai jamais été tenté d'écrire en flamand, quoique ce soit ma langue maternelle et que politiquement je me sens de cœur avec les revendications des flamands. A l'école, jeétais un excellent sujet pour la composition française et nul pour la néerlandaise. Maintenant encore, quoique j'écrive facilement le néerlandais, je dispose dans cette langue d'un vocabulaire beaucoup plus restreint. (Letter to Léon Treich, 20/10/1925)

The reference to his mother tongue and to the political demands of the Flemings illustrates a sense of guilt and shame as well as the internal struggles typical of intercultural mediators belonging to different groups in whose minds different logics clash (Lahire, 2004, p.60). Towards his Flemish colleagues, Avermaete therefore took a defensive attitude: he admits that he had "no excuse whatsoever"18 for his language choice, except "the dominant influence of the French culture"19 (Florquin, 1962, p. 5). The linguistic socialization in French and the interiorization

17. Lahire (2006, p. 495) sees this love for reading as a disposition that is largely formed by family and school experiences.

18. "geen enkel ekskuus"

19. "de overwegende invloed van de Franse kultuur" 
of the dominant position of French lead to a certain alienation from his mother tongue: "When I later wanted to write in Dutch, I needed to learn it. Writing in French went spontaneously and even now I express myself more easily in French" (ibid., pp. 5-6). ${ }^{20}$ It did not, however, prevent him from quickly becoming a bilingual writer. His debut in Dutch dates back to 1924, barely five years after his first French publication, and it was a self-translation. ${ }^{21}$ He continued translating some of his own works ${ }^{22}$ and always considered them as separate originals rather than translations. In addition, he continued to publish both in French and Dutch ${ }^{23}$ in the most diverse genres: prose, poetry, literary and artistic criticism, theatre, (literary, artistic, political) essays, scenarios for ballet, polemics, and he collaborated in Francophone and Dutch-speaking Belgian, Dutch, French, German, and Brazilian magazines (see Letter to Jacoby, 1930). As a critic he wrote about Flemish literature in the Francophone Belgian newspaper L'Indépendance Belge (1936-1939) and about international art and literature in the Dutch Belgian Volksgazet [People's Gazette] (1931-1938). At the same time, he developed wide range of paraliterary activities. Not only was he editor-in-chief of the magazine Lumière (1919-1923) and director of a publishing house carrying the same name, ${ }^{24}$ he also organized exhibitions and conferences. All these (para-)literary activities were characterized by FrenchDutch bilingualism.

20. "Toen ik later in het Nederlands wou schrijven, heb ik dat moeten leren. Frans schreef ik vanzelf en nu nog druk ik mij gemakkelijker uit in het Frans." This vision is shared by contemporaries of Avermaete; see e.g. Eeckhout (1932).

21. Een voorbeeldige vrouw (1924) is a self-translation of Une épouse modèle (1923). It faithfully follows the French original.

22. The play Meester van de Zee (1931) is a self-translation of Maitre de la Mer (1931). Avermaete considers the translation as "une pièce originale." (Letter to Poupeye, 22/4/1931)

23. The relationship between the two languages is about $25 \%$ Dutch vs. 75\% French. Avermaete published 12 Dutch-language works that did not appear in French and 14 bilingual works, all belonging to the domain of the arts.

24. Between 1920 and 1934, Lumière published 65 volumes. One fourth are art books, one-sixth are Dutch-language publications, both translations into Dutch and originals. Lumière also published translations of Flemish, Russian, and German writers in French (Lemaire, 1969, pp. 8-15). 
As this overview makes clear, it would be reductive to confine an intercultural mediator like Avermaete to a single language, artistic activity or cultural group. He was active across all these borders-without necessarily erasing them-thereby configuring his own hybrid (i.e. national as well as international, intercultural and inter-artistic) positions (see also below). Relative to his contemporaries, Avermaete again occupied an intermediate position between bilingual Flemings who wrote only in Dutch ${ }^{25}$ or only in French, although they theoretically could have become self-translators or multilingual writers (Meylaerts, 2010). In his literary career, Avermaete thus continued to practice the (largely trouble-free) bilingualism that was an inherent part of his earliest socialization and partly characterized his professional career, although in contrast to his education and profession, the dominant language occupied an even more prominent place in his literary activities. However, in a multilingual society where the different languages and literatures represent oppositional logics that are closely associated with sociopolitical and sociocultural oppositions, literary multilingualism and multiple transfer roles such as translation and self-translation continuously risk giving rise to habitus-field clashes and to more or less important intra-individual variations and oppositions in perceptions and practices. The perceptions and practices of intercultural mediators like Avermaete have to be understood in light of this fact; he cannot be reduced to his "being-member-of-one-field" ${ }^{26}$ I will now attempt to illustrate this point with respect to some of his transfer roles.

Along with a number of other young Antwerpians of Flemish origin, ${ }^{27}$ Avermaete co-founded the magazine Lumiere (1919$1923)$ in 1919. The magazine's editorial staff included bilinguals

25. For instance, Ernest Claes (Meylaerts, 2008).

26. "être-comme-membre-du-champ" (Lahire, 2006, p. 27).

27. In addition to Avermaete, the group was composed of four writers (Willy Koninckx, Georges Marlier, René Vaes, Bob Claessens) and two painters (Alice Frey and Joris Minne). Vaes and Minne were colleagues. As head of office Avermaete shared an office with Minne who worked there part time as librarian (Wilson, 1993, p. 18). According to de Marneffe (2007), in this way they felt less weakened by the linguistic conflict and by the difficult economic situation created by WWI. Marneffe ignores, however, possible habitus-field clashes. See also below. 
who, like him, came from Flemish families and were often fellow officials in the Antwerp administration; Avermaete's professional life was thus partly connected with his literary activities. The title of the magazine was inspired by the Parisian Clarté movement led by Henri Barbusse whose aim was to unite the pacifist movements of France and Europe. The magazine was further connected to the international humanism defended by Romain Rolland in his Déclaration d'Indépendance de l'esprit (1919), which united some thousand writers worldwide. As director of Lumière, Avermaete incarnated everything the magazine stood for: internationalist, politically independent, anti-bourgeois, progressive, revolutionary and pacifist. The fraternization between the peoples promoted by the international humanism was to lead to new ideas and new art. He pushed this idea very far by seeking a rapprochement with German writers shortly after the war, an attitude that did not sit well with some colleagues:

Voici: lors du congrès de Londres j’ai eu des démêlés avec Piérard parce qu'il avait eu l'audace de s'opposer à la venue de la délégation allemande et ce au nom des écrivains belges. (Letter to Duhamel, 2/10/1927).

Avermaete published Lumière in French because of its international status and readers (Pais-Minne, 1993, p. 38). Not surprisingly, for some Flemings the magazine was reputed to be the meeting place of the franskiljons (Florquin, 1962, p. 19), ${ }^{28}$ and Avermaete had to defend himself against accusations of treason against Flanders and its desire for cultural and political emancipation.

Maar Wies Moens werkte aan ons tijdschrift mee. Trouwens, bij de franskiljons hadden wij de reputatie flaminganten te zijn. Frans was toen een uiting van een kaste politiek die wij heftig bestreden. Ik droomde in die tijd, samen met Firmin Mortier en Herman van Reeck alstublieft een internationale van de jeugd te stichten. Frans van de Wijngaard heeft nooit een letter in het Frans geschreven, maar werkte mee: wij vertaalden hem eenvoudig. Ten andere op dat ogenblik hadden wij met evenveel plezier Chinees uitgegeven. [...] Door de taal

28. Franskiljon was a strong term of abuse used by Dutch-speaking Flemings to refer to gallicized, pro-French Flemings like Avermaete. 
zelf speelde ik op groter vlak en kon een internationaal publiek bereiken. (Florquin, 1962, pp. 19-20)

[But Wies Moens collaborated with our magazine. Besides, in the eyes of the pro-French Flemings we had the reputation of being supporters of the Flemish movement. French was at that time an expression of a caste politics that we violently contested. I dreamed at that time, along with Firmin Mortier and Herman van Reeck, there now, of an International of the youth. Frank van de Wijngaard has never written one letter in French, but collaborated: we simply translated him. Moreover, at that moment we would have published him with just as much pleasure in Chinese. [...] Because of the language itself I played on a larger plane and could reach an international audience.]

As a bilingual intercultural mediator raised in between languages and cultures, Avermaete aimed to transgress linguistic, literary and national borders, but, in so doing, he clashed with field logics, according to which positions were progressively defined by monolingualism. Therefore he dissociated himself from the view of French as an instrument of national oppression used by the Francophones towards the Flemings. He saw it rather as a lingua franca, a neutral medium for international radiation and fraternization, and therefore easily replaceable with another language such as Chinese. Accordingly, language use had to be disconnected from the intranational, sociocultural and sociopolitical oppositions it symbolized, and translation should be seen as an unproblematic means to internationalization and fraternization. From this perspective, the status of a translated text as a translation is irrelevant. Indeed, Avermaete's translations of Flemish literature for Lumière appeared without his name as translator. ${ }^{29}$ Furthermore, the neutralization of French as an instrument of national oppression against the Flemings should not only allow for the defense of the Flemish cause in French, it should also allow one to realize the Clarté ideals together

29. For instance, "In de Branding" [In the surf] by Jef Horemans and "Heilige Nacht" [Holy Night] by Lode Baekelmans, resp. in nr. 7, 1920 and nr. 7, 1921. Horemans also had to deal with allegations of activism (see Letter of Avermaete to Horemans, 22/12/1919), although for Avermaete this was no reason not to publish him. 
with Flemish activists like Moens, van den Reeck and Mortier. ${ }^{30}$ At a time when the struggle for the linguistic and cultural emancipation of the Flemings was incarnated by the slogan "De taal is gansch het volk" [The language is the people], and when literary (and political) positions in the field were closely linked to linguistic oppositions and polarizations (Flemish militants vs. franskiljons), Avermaete again tried to occupy an intermediate intercultural position. Although he remained faithful to his earliest socialization, he was nonetheless aware of the idealistic nature of his position:

More peculiar than these contributions [translations of Flemish writers] was, I believe, our attitude of mind. We were indeed decidedly internationalist-individualist, French-writing Flemish militants. This variety of the human fauna has remained a rarity." (Letter to Ger Schmook, 3/9/1959) ${ }^{31}$

In short, as an intercultural mediator Avermaete was part of different, largely irreconcilable groups, and he saw himself confronted with different oppositional field logics. Given the heterogeneous - as opposed to homogenous-nature of the cultural situations in which he found himself, intra-individual variations in his practices, perceptions and attitudes were to be expected both from a synchronic and diachronic viewpoint (Lahire, 2006).

30. The activists formed a small group of Flemings who strove for radical political changes to ensure the greatest possible political independence for Flanders. During WWI they collaborated with the German occupiers. (Nieuwe Encyclopedie van de Vlaamse beweging, n. p.). Wies Moens (1898-1982) was convicted in 1920 to four years of imprisonment for activism. During his imprisonment, he wrote Celbrieven [Cell letters]; one of the letters was published in Lumière. Herman van den Reeck (19011920) was shot during the Golden Spurs Celebration on 12 July 1920. He linked his sympathy for the Flemish movement to pacifist and communist ideals and was a member of the Flemish Clarté group (Nieuwe Encyclopedie van de Vlaamse beweging, n. p.). Mortier (1899-1972) was a friend of van den Reeck, activist and member of the Flemish Clarté group (Nieuwe Encyclopedie van de Vlaamse beweging, n. p.).

31. Eigenaardiger dan deze bijdragen [vertalingen van Vlaamse schrijvers] was, meen ik,onze geesteshouding. We waren toch beslist internationalistischeindividualistische fransschrijvende [sic] flaminganten. Deze variëteit van de menselijke fauna is trouwens een zeldzaamheid gebleven. 


\section{Multiple Positions}

Indeed, from the very beginning of his activities as an intercultural mediator, Avermaete occupied both "Flemish" and "Francophone" positions. In accordance with his multipositionality, he saw himself as belonging at once to the Flemish and to the Francophone Belgian literatures and cultures. His relationship with the Flemish writers gave rise to feelings of internal struggle, typical for intercultural mediators who belong to different groups and are confronted with oppositional field logics. In this respect, the combination of writing in French and claiming a Flemish identity may have given rise to internal conflict: "Encore que j'écrive beaucoup plus en français qu'en néerlandais, les Flamands ne m’ont jamais renié parce que je n'ai pas renié une communauté à laquelle j'appartiens de naissance" (Letter to L. Anciaux, 18/1/1965). He nonetheless maintained good relations with (bilingual) Flemish writers, with whom, in conformity with his ideal of bilingualism and his views on language as a neutral communication medium, he corresponded alternately in French and Dutch. ${ }^{32} \mathrm{He}$ further acted as a mediator for Flemish theatre in Paris.

Myn vriend Paul Blanchart, die secretaris is van de "Société Universelle du Théâtre," schryft me, met betrekking op het a.s. Congres van deze groepeering: "j'aimerais beaucoup personnellement que vous puissiez nous amener un 'as' d'expression flamande." Ik zend U hierbij het programma van het congres. Interesseert het $\mathrm{U}$ het Vlaamsche tooneel te Parys te vertegenwoordigen? (Letter to H. Teirlinck, 11/5/1937) ${ }^{33}$

[My friend Paul Blanchart, who is Secretary of the "Société Universelle du Théâtre," writes to me, on the subject of this association's forthcoming congress: "I would like very much that you could bring us along a Flemish star." I send to you the program of the Congress. Are you interested in representing the Flemish theater in Paris?]

32. For example, Avermaete corresponded with the bilingual Fleming André de Ridder sometimes in French, sometimes in Dutch.

33. Also towards his French colleague Duhamel Avermaete expresses his indignation: "A Anvers la municipalité n'a pas voulu inviter les écrivains anversois de langue française" (Letter to Duhamel, 2/10/1927). 
As in the case of his language choice, Avermaete's role as an intercultural mediator clashed with changing cultural and political field structures in which positions were increasingly defined by monolingualism. During the interwar period, public life in Antwerp became more and more Flemish; consequently, Francophone Flemish writers were not always welcome at official events. Avermaete apologized to his Flemish colleagues for his undesired exclusion from Flemish literary life:

Waarde Heer Baekelmans, Tot mijn groote spijt kan ik morgen niet aanwezig zijn noch op de plechtige ontvangst op het stadhuis noch op het gezellig samenzijn in Club Artes. [...] Ik vind het bizonder (sic) vervelend voor mij omdat het me ook niet gegund werd U mijn sympathie te betuigen in de uitgave van het huldecomité. Deze heeren stelden wellicht geen belang in de opinie van fransch schrijvende vlamingen. Dit is natuurlijk hun recht. Maar ik zou niet graag bij $\mathrm{U}$ den indruk wekken dat mijn afwezigheid - in beide gevallen - aan gemis van belangstelling te wijten is. (Letter to Lode Baekelmans, 29/5/1926)

[Dear Mr Baekelmans, To my great regret, I cannot be present tomorrow at the solemn reception at the town hall or at the cozy get-together in Club Artes. [...] I find this particularly annoying because I was not permitted either to express to you my sympathy in the publication of the tribute Committee. These gentlemen were probably not interested in the opinion of French-writing Flemings. This is of course their right. But I would not like to give you the impression that my absence-in both cases-is due to a lack of interest.]

Subject to intra-individual variations, Avermaete shared on the other hand certain stereotypical Francophone perceptions of Flemish culture, such as the condescending attitude of Francophones with respect to so-called popular Flanders. He wrote to a Francophone colleague, after having attended his play Le Maître de la mer in Dutch translation: "J'ai été la [De Meester van de zee] revoir devant le public ordinaire du Flamand et j'ai été épaté de constater à quel point ce brave public marchait!" (Letter to Poupeye, 24/12/1931; my italics). The perception of Flemish and Flanders as popular, obedient and naive was 
widespread among the French-speaking upper classes during the interwar period, much to the disapproval of the emancipation movement (Meylaerts, 2004). In contrast to the militant Flemish position he had defended just after the war $^{34}$ and at a moment when the objective structures of the fields of administration and education with regard to language were being redrawn, ${ }^{35}$ Avermaete continued, faithful to his own linguistic socialization, to defend bilingual education in Flanders. At the literary-cultural level he was also against the pro-Flemish vision that bilingualism makes an indigenous art impossible, that is, against a remapping of the structures of the Flemish literary field in function of monolingualism.

Maar het valt toch niet te loochenen dat, in de XVe en in de XVIe eeuw, onze Nederlandsche gewesten een autochtone kunst en literatuur geproduceerd hebben, ondanks officieele tweetaligheid. Ik wil er verder geen conclusies uit trekken. Ik ben het volkomen eens met eentaligheid in het lager onderwijs, omdat ik vind dat de menschen het recht moeten hebben in hun eigen taal opgevoed te worden. Ik ben minder overtuigd van de noodlottige gevolgen eener zekere tweetaligheid. [...] Men is Vlaanderen aan het afzonderen en dat vind ik een ramp. [...] Maar als wy voortgaan op de weg dien we thans bewandelen dan zullen de Vlaamsche jongens en meisjes die de hoogeschool verlaten, op enkele uitzonderingen na, niet meer by machte zyn zich in een tweede taal uit te drukken. [...] Wanneer het Fransch in Vlaanderen zal verdrongen zyn tot een volledige vreemde taal, zooals het Duitsch, dan zullen we wel de theorie van het Germanendom zien verschijnen en dan ligt inderdaad het veld voor propaganda open. Ik heb nu al gelezen dat de Vlamingen naar Nurenberg zien als naar hun Mekka. [...] Los van Frankrijk, politiek gesproken, is goed, maar los van de fransche cultuur om ons de Duitsche op te solferen is een gevaar van ideologischen aard dat niemand schynt te beseffen. (Letter to Herman Vos, 1/11/1938)

34. In March 1920 he defended in Lumière the right to a Dutch-language University in Ghent as well as administrative monolingualism: Dutch in Flanders and French in Wallonia.

35. The laws for monolingual (Dutch) primary and secondary education and administration in Flanders were passed in 1932. Since 1930 the Ghent University has been a Dutch-language university. 
[But it cannot be denied that, in the 15th and 16th century, our Dutch regions produced an indigenous art and literature, in spite of official bilingualism. I will not draw any further conclusions. I agree entirely with monolingualism in primary education, because I believe that the people should have the right to be educated in their own language. I am less convinced of the fateful consequences of a certain bilingualism. [...] One is trying to isolate Flanders, and I think that this is a disaster. But if we continue on the road that we now follow then the Flemish boys and girls who finish college will, with few exceptions, no longer be able to express themselves in a second language. [...] When French in Flanders will be suppressed to a fully foreign language, like German, then we shall see the theory of Germanism appear and the field for propaganda will be opened. I have already read that the Flemings look toward Nürenberg as if it were their Mecca. Being independent from France is good, politically speaking, but being isolated from the French culture to palm the German one off on us presents a danger of an ideological nature that no one seems to realize.]

Just as he did after World War I, Avermaete still perceived French not as an instrument of national oppression but as a synonym for internationalism and pacifism; however, this time it was in explicit opposition to German and its association with Nazi ideology. As a bilingual Fleming with a linguistic and cultural socialization in French language and culture, Avermaete's position had moved progressively away from that of the supporters of the Flemish movement ${ }^{36}$ in favor of his internalization of the dominant status of French. The internal struggle resulting from the confrontation between the perception schemes of his earliest socialization and the changing (sociolinguistic) structures of the cultural and

36. More than three decades later he repeated the same lament: "Men moet m.i. nooit gesloten zijn voor om het even welke kultuur en de Vlamingen hebben perfect bewezen dat ze zonder moeite vreemde invloeden trotseren. Ik ben een Vlaming en houd van Vlamingen, hetgeen me niet belet dat de Vlamingen (niet alle) me soms verbazen door hun enggeestigheid" (Letter to F. Coenaarts, 24/11/1962). ["One must never remain closed to any culture and the Flemings have proved to perfection that they defy foreign influences without difficulty. I am a Fleming and love Flemings, which does not prevent the Flemings (not all) from amazing me sometimes by their narrow-mindedness."] 
political field is very clear in the following excerpt.

Anvers a beaucoup souffert, sur le plan artistique, de la néfaste politique linguistique que les représentants du peuple nous ont imposée dans l'entre-deux-guerres. Combien d'organisateurs ne se sont pas demandé, perplexes, dans quelle langue il fallait annoncer certaines manifestations? En flamand, pour satisfaire aux exigences de ceux qui parlaient soi-disant au nom du peuple et de ses droits souverains? C'était, bien souvent le sûr moyen de jouer devant des banquettes. En français, pour avoir "des clients"? C'était se faire mal voir par une masse de braves gens qui y voyaient, pour le moins, l'intervention sournoise d'une puissance étrangère. Dans les deux langues? Quelques conciliants usèrent de ce moyen. C'était le moyen infaillible pour se mettre tout le monde à dos. (Avermaete, 1945, n. p.)

For Avermaete, there is only one future for Belgium and for the country's unity: official bilingualism. In 1938 he defended these ideas in his essay La Belgique se meurt. At that moment, linguistic laws based on the territorial principle for education, administration and justice (Dutch in Flanders, French in Wallonia, bilingualism in Brussels) had already been in effect for several years.

\section{Conclusion}

As has been illustrated by the case of Roger Avermaete, habitus is a useful concept for whoever wants to understand the attitudes, perceptions, beliefs and positions of translators or intercultural mediators at large. However, it is essential in this regard to conceptualize it in the sense of the critical reorientation given by Bernard Lahire. The Lahirian habitus is fragmented, plural, dynamic and at times even contradictory. It allows for intraindividual variations, for shifting between fields, for habitusfield clashes and for dispositions that become active only under certain circumstances. As such, it offers a powerful analytical tool for studying the self-images, perceptions and complex transfer activities of literary translators, operating in the weakly (or non) autonomized field of literary translation. For these intercultural mediators translating is usually part of an aggregate of partly overlapping, literary (transfer) roles which include 
writing, translating, multilingual writing, self-translating, publishing and is a secondary activity in addition to their actual professional life (as a civil servant, a teacher, a publisher, etc.). Such a translator's habitus is therefore the unique integration of his/her cultural socialization in terms of family and social environment, schooling, professional career, contacts with social, political, religious and cultural institutions, etc. A nuanced understanding of literary translators' self-images, perceptions and transfer activities in cultural history therefore requires detailed analyses of their multipositionality as it relates to their multiple lives and to their plural and variable socialisation in a variety of social and cultural contexts. For intercultural mediators living in a multilingual culture, such as Avermaete, this socialization is inevitably linked both to the perceived-and sometimes problematic-relationships between the different languages, literatures and cultures and to their evolution over time. In the case of oppositional relations between the languages and cultures involved, these intercultural mediators' writing, translating, publishing and editing activities are bound to lead to internal struggles and habitus-field clashes. These clashes illustrate the dynamic relationships between habitus and field and between structure and agency; they further emphasize the discontinuity and plurality of intercultural trajectories. Finally, they make us aware of the difficulties of being a translator in a multilingual culture. From a conceptual viewpoint, they point to the actual overlapping of transfer roles such as translator, multilingual writer or critic or self-translator which are usually conceptualized as mutually exclusive.

\section{References}

Avermaete, Alain (September 2011). Interview.

Avermaete, Roger (1945). "Un article de Roger Avermaete. Anvers 'Métropole des Arts." Le Matin, 12/12/1945.

Beckers, Ria (1976). "Het Frans in de lagere scholen van Antwerpen rond 1981." Antwerpen. Driemaandelijks tijdschrift van de stad Antwerpen, 3, September, pp. 170-180.

Bourdieu, Pierre (1980). Le sens pratique. Paris, Éditions de Minuit.

Bourdieu, Pierre (1997). Méditations pascaliennes. Paris, Seuil.

Bourdieu, Pierre (2000 [1972]). Esquisse d'une théorie de la pratique précédé de trois études d'ethnologie kabyle. Paris, Seuil. 
Correspondence Roger Avermaete, conserved at the Letterenhuis, Antwerp, dossier A493.

Denuit, Désiré (1978). Roger Avermaete, le non-conformiste. Bruxelles, Fonds Mercator.

Eeckhout, Joris (1932). Litteraire Profielen, 5, Gent, Vanmelle.

Florquin, Joos (1962). Ten buize van... Roger Avermaete. Manuscript of the television program conserved at the Letterenhuis, Antwerp, dossier A493.

Gambier, Yves (2006). "Pour une socio-traduction." In J. F. Duarte, A. Assis Rosa and T. Seruya, eds. Translation Studies at the Interface of Disciplines. Amsterdam/Philadelphia, John Benjamins, pp. 29-42.

Gouanvic, Jean-Marc (1997). "Translation and the Shape of Things to Come. The Emergence of American Science Fiction in Post-War France." The Translator, 3, 2, pp. 125-152.

Gouanvic, Jean-Marc (1999). Sociologie de la traduction. La science-fiction américaine dans l'espace culturel français des années 1950. Arras Cedex, Artois Presses Université.

Hanna, Sameh F. (2005). "Hamlet Lives Happily Ever After in Arabic. The Genesis of the Field of Drama Translation in Egypt." The Translator, 11, 2, pp. 167-192.

Inghilleri, Moira (2003). "Habitus, Field and Discourse. Interpreting as a Socially Situated Activity.” Target, 15, 2, pp. 243-268.

Inghilleri, Moira (2005). "The Sociology of Bourdieu and the Construction of the 'Object' in Translation and Interpreting Studies.” The Translator, 11, 2, pp. 125-145.

Lahire, Bernard (1998). L'homme pluriel. Les ressorts de l'action. Paris, Hachette.

Lahire, Bernard, ed. (2001). Le travail sociologique de Pierre Bourdieu. Dettes et critiques. Paris, La Découverte.

Lahire, Bernard (2003). "From the Habitus to an Individual Heritage of Dispositions. Towards a Sociology at the Level of the Individual." Poetics, 31, 5-6, pp. 329-355.

Lahire, Bernard (2004). La culture des individus: dissonances culturelles et distinction de soi. Paris, La Découverte.

Lahire, Bernard (2006). La condition littéraire: la double vie des écrivains. Paris, La Découverte.

Lemaire, Claudine (1969). Le Groupe "Lumière". Bruxelles, Bibliothèque royale.

Marneffe, Daphné de (2007). Entre modernisme et avant-garde. Le réseau des revues littéraires de l'immédiat après-guerre en Belgique (1919-1922). Thèse de doctorat. [http://bictel.ulg.ac.be/ETD-db/ 
collection/available/ULgetd-09292007-212823/].

Meylaerts, Reine (2004). L'Aventure flamande de la Revue Belge: langues, littératures et cultures dans l'entre-deux-guerres. Bruxelles, P. I. E., Peter Lang, Archives et Musée de la Littérature.

Meylaerts, Reine (2007). "La Belgique vivra-t-elle? Language and Translation Ideological Debates in Belgium (1919-1940)." The Translator, 13, 2, pp. 297-319.

Meylaerts, Reine (2008). "Translators and (their) Norms: Towards a Sociological Construction of the Individual.” In M. Shlesinger, D. Simeoni and A. Pym, eds. Beyond Descriptive Translation Studies. Investigations in Homage to Gideon Toury. Amsterdam/Philadelphia, John Benjamins, pp. 91-102.

Meylaerts, Reine (2009). “Et pour les Flamands la même chose': quelle politique de traduction pour quelles minorités linguistiques?” Meta, 54,1 , pp. 7-21.

Meylaerts, Reine (2010). "Au-delà des oppositions binaires national/ international, traduit/non traduit: les relations littéraires hier, aujourd'hui et demain.”TTR, XXII, 2, pp. 93-117.

Nieuwe Encyclopedie van de Vlaamse Beweging, online version. [https:// services.libis.be/v0/primo/query_builder?query=MLKUL01252\&s cope $=$ all $]$.

Pais-Minne, Eva (1993). “Spil van de groep 'Lumière'.”In W. Coudenys, L. Daan, and A. Germoz, eds. Roger Baron Avermaete. Honderd jaar jong. Antwerpen, Vrienden van Roger Avermaete, pp. 37-48.

Sela-Sheffy, Rakefet (2005). "How to Be a (Recognized) Translator: Rethinking Habitus, Norms, and the Field of Translation." Target, 17, 1, pp. 1-26.

Shlesinger, Miriam and Rakefet Sela-Sheffy, eds. (2011). Identity and Status in the Translational Professions. Amsterdam/Philadelphia, John Benjamins.

Simeoni, Daniel (1998). “The Pivotal Status of the Translator's Habitus.” Target, 10, 1, pp. 1-39.

Van der Ven, Flor (1909). Het Weldadigheidsbureel van Antwerpen. Antwerpen, Boekhandel Van der Van en Zoon.

Wils, Lode. (2008). "Het officiële taalgebruik in Vlaanderen in de negentiende eeuw." Wetenschappelijke tijdingen op het gebied van de geschiedenis van de Vlaamse Berveging, 67, 2, pp. 115-127.

Wilson, John (1993). "De ambtenaar". In W. Coudenys, L. Daan, and A. Germoz, eds. Roger Baron Avermaete. Honderd jaar jong. Antwerpen, Vrienden van Roger Avermaete, pp. 15-22. 
Wolf, Michaela and Alexandra Fukari, eds. (2007). Constructing a Sociology of Translation. Amsterdam/Philadelphia, John Benjamins.

Reine MEYLAERTS

Translation Studies \& Comparative Literature

Faculty of Arts KU Leuven

Blijde-Inkomststraat 21 Bus 3310

3000 Leuven

BELGIUM

reine.meylaerts@arts.kuleuven.be 